\title{
Negative-Expected-Value Suits
}

\section{Citation}

Lucian Bebchuk and Alon Klement, Negative Expected-Value Suits (Harvard John M. Olin Discussion Paper Series, No. 656, Dec. 2009).

\section{Published Version}

http://www.law.harvard.edu/programs/olin_center/papers/pdf/Bebchuk_656.pdf

\section{Permanent link}

http://nrs.harvard.edu/urn-3:HUL.InstRepos:30064399

\section{Terms of Use}

This article was downloaded from Harvard University's DASH repository, and is made available under the terms and conditions applicable to Other Posted Material, as set forth at http:// nrs.harvard.edu/urn-3:HUL.InstRepos:dash.current.terms-of-use\#LAA

\section{Share Your Story}

The Harvard community has made this article openly available.

Please share how this access benefits you. Submit a story.

Accessibility 
ISSN 1045-6333

\section{HARVARD}

JOHn M. Olin CENTER FOR LAW, ECONOMICS, AND BUSINESS

\section{NEGATIVE-EXPECTED-VALUE SUITS}

Lucian A. Bebchuk and Alon Klement

Discussion Paper No. 656

$12 / 2009$

Harvard Law School

Cambridge, MA 02138

This paper can be downloaded without charge from:

The Harvard John M. Olin Discussion Paper Series:

http://www.law.harvard.edu/programs/olin_center/

The Social Science Research Network Electronic Paper Collection:

http://ssrn.com/abstract=1534703 
Forthcoming, Elgar Encyclopedia of Law and Economics ( $2^{\text {nd }}$ Edition)

\title{
NEGATIVE EXPECTED-VALUE SUITS
}

\author{
Lucian A. Bebchuk ${ }^{*}$ and Alon Klement ${ }^{* *}$
}

\begin{abstract}
$\underline{\text { Abstract }}$
We review the literature on negative-expected-value suits (NEV suits) suits in which the plaintiff would obtain a negative expected return from pursuing the suit all the way to judgment. We discuss alternative theories as to why, and when, plaintiffs with NEV suits can extract a positive settlement amount. In particular, we explain how such a plaintiff can extract a positive settlement due (i) asymmetry of information between the parties, (ii) divisibility of the plaintiff's litigation costs, (iii) upfront costs that the defendant must incur before the plaintiff incurs any costs; (iv) expectation that the arrival of information during the course of the litigation may turn the suit into a positive-expected-value one, (5) reputation that enables the plaintiff to bind itself to going to trial if the defendant refuses to settle; or (6) the plaintiff's having a contingency fee or retainer arrangement with its lawyer.
\end{abstract}

Keywords: Litigation, settlement, frivolous suits, negative expected value suits, positive expected value suit, divisibility, credibility, fee-shifting, contingent fees, retainer.

JEL Classification: K19, K41

\footnotetext{
${ }^{*}$ William J. Friedman and Alicia Townsend Friedman Professor of Law, Economics, and Finance, Harvard Law School.

** Professor of Law, Radzyner School of Law, Interdisciplinary Center Herzliya

This paper builds on an earlier review on this subject, Bebchuk, Suits with Negative Expected Value, 3 The New Palgrave Dictionary of Economics and the Law 551-554 (University of Chicago Press, 2000). The authors are grateful to Omer Belsky for his research assistance. Lucian Bebchuk also would like to thank the Harvard John M. Olin Center for Law, Economics, and Business for financial support.
} 


\section{NEgATIVE EXPECTED-VALUE SUITS}

(c) Lucian Bebchuk and Alon Klement

This essay reviews the state of knowledge about why (and when) plaintiffs with negativeexpected-value suits can extract a positive settlement amount from the defendant. The literature on the subject has continued to grow since the publication of the earlier review of Bebchuk (2000), and we attempt to reflect in this paper all the advances made since that time.

DEFINITION OF NEV SUITS. A negative-expected-value (NEV) suit is one in which the plaintiff would obtain a negative expected return from pursuing the suit all the way to judgment -- that is, one in which the plaintiff's expected total litigation costs would exceed the expected judgment. Thus, denoting by $C p$ and $C d$ the total litigation costs of the plaintiff and the defendant respectively and by $W$ the expected judgment, a suit is an NEV suit if $C p>W$.

It should be emphasized that an NEV suit need not be a frivolous suit -- that is, a suit in which the plaintiff is unlikely to win. The expected judgment is a product of the likelihood of a plaintiff's victory and the amount at stake. Therefore, a meritorious suit -- one in which the likelihood of a plaintiff victory is quite high -- might be NEV if the litigation costs involved are sufficiently large relative to the amount at stake.

THE PUZZLE OF NEV SUITS. It is generally believed that cases with NEV suits are abundant, and that plaintiffs with NEV suits are frequently able to extract a positive amount from the defendant to settle the case. But why would a rational defendant agree to pay any settlement amount to a plaintiff with an NEV suit? This is the question that the literature has sought to answer.

The early literature on litigation has largely abstracted from the question of NEV suits (see Gould (1973), Landes (1971), and Posner (1973)). And the first papers on litigation decisions under asymmetric information (see, Bebchuk (1984), P'ng (1983) and Reinganum and Wilde (1986)) have explicitly limited their analysis to cases in which the plaintiff's suit is known to have a positive expected value (a PEV suit). But work done since the mid-80's has put forward 
a number of explanations for the potential success of plaintiffs with NEV suits to extract a settlement. This literature has shown that a plaintiff with an NEV suit will not be able to extract a settlement offer only if the following assumptions are satisfied:

(1) There is no asymmetry of information between the parties;

(2) The plaintiff's litigation costs are not divisible;

(3) The defendant does not have to incur some upfront costs before the plaintiff incurs any costs;

(4) The expected value of the judgment is expected to remain below total litigation costs throughout the litigation;

(5) The plaintiff does not have a reputation that enables it to bind itself to going to trial if the defendant refuses to settle; and

(6) The plaintiff does not employ some special contractual arrangements with the plaintiff's lawyer.

The following discussion demonstrates how relaxing each of these assumptions allows the NEV plaintiff to extract a settlement.

\section{(1) ASYMMETRIC INFORMATION.}

Since the early 80's much of the literature on litigation has focused on the consequences of asymmetric information, using a model of litigation decisions under asymmetric information put forward in Bebchuk (1984). As it turns out, the presence of an informational asymmetry is also relevant to NEV suits. Bebchuk (1988) extended the model of litigation decisions under asymmetric information of Bebchuk (1984) to NEV suits and demonstrated that the presence of an informational asymmetry can explain the success of some NEV suits. The asymmetric information explanation was also subsequently examined by Katz (1990).

To see the role that asymmetric information can play in this context, consider the situation of a defendant who does not know whether the expected value to the plaintiff from going to trial is positive or negative. This uncertainty might result from private information that the plaintiff has either about her litigation costs, $C_{p}$ or about the expected judgment $W$. In this case, in deciding whether to make a positive settlement offer to the plaintiff, the defendant will consider two possibilities. On the one hand, the plaintiff might have an NEV suit, in which case offering to settle would be wasteful since the plaintiff would not go to trial anyway. On the other 
hand, the plaintiff might have a PEV suit, in which case making a settlement offer would possibly prevent litigation and produce a beneficial settlement. Balancing these two considerations, the defendant might elect to make a settlement offer, which the plaintiff will of course take if the plaintiff's suit is in fact an NEV suit.

It is possible to derive the conditions under which a plaintiff with an NEV suit can extract a settlement offer due to the presence of informational asymmetry (see Bebchuk (1988, pp. 4456). For example, the greater the defendant's expected litigation costs and the lower the probability attached by the defendant to the suit being an NEV suit the more likely the possibility that the defendant will make a settlement offer.

Finally, the plaintiff's private information may be revealed through pre-trial discovery and disclosure. As Schwartz (2003) and Schwartz and Wickelgren (2009a) suggest, if defendants' costs of pre-trial discovery are sufficiently low, it may allow them to separate between NEV and PEV plaintiffs and render the litigation threat of NEV plaintiffs non-credible.

\section{(2) DIVISIBILITY OF LITIGATION COSTS.}

Bebchuk $(1996,1997)$ has shown that the divisibility of the litigation process can provide a plaintiff with a credible threat, and enable it to extract a settlement, even if the plaintiff is known by the defendant to have an NEV suit. What underlies the considered explanation is the recognition that litigation costs are generally not incurred all at once in a lump-sum fashion -- but rather are spread over a period of time, with bargaining possibly taking place on numerous occasions throughout this period. This divisibility turns out to play an important strategic role.

To see the strategic implications of divisibility, consider a case in which $W$ is 100 and $C p$ and $C d$ are both 120. Initially, suppose that there is only one litigation stage in which all of the parties' litigation costs must be incurred in a lump-sum, indivisible fashion. In this case, in the negotiations preceding this indivisible stage, the plaintiff will not have a credible threat; for, if the defendant refuses to settle, the plaintiff can be expected to drop its case. Anticipating this, the defendant will refuse to settle for any positive amount.

Suppose, however, that the litigation costs in the case under consideration are expected be incurred in two equal-cost stages and that the parties can engage in settlement negotiations not only before the first stage but also between the two stages. Analyzing this case by backward induction, let us start by considering the bargaining round between the two stages. Assuming that 
the parties reach this round, the plaintiff will have a credible threat to proceed to judgment. At this stage, the cost of the first stage of litigation is already sunk, and going all the way to judgment would provide an expected judgment of 100 and involve an additional cost of only 60 .

Thus, if the parties somehow reach the bargaining round between the two stages, the plaintiff will have a credible threat and will be able to extract a settlement. Since the expected judgment is 100 , and each party faces an additional cost of 60 , the parties can be expected to settle at some point in the range between 40 and 160, with the location of the point depending on the parties' relative bargaining power.

Now suppose that should the parties reach the bargaining round between the two litigation stages, the plaintiff can be expected to obtain a settlement amount that exceeds 60 . And let us proceed in the process of backward induction one stage back in time. In the bargaining round before the first litigation stage it is now the case that the plaintiff will have a credible threat to proceed through this litigation stage. For proceeding through the first stage will cost the plaintiff 60 but can be expected to provide the plaintiff with a settlement amount exceeding 60 . The presence of this credible threat to proceed will enable the plaintiff to extract a settlement offer in the bargaining round preceding the first stage of litigation.

The above example shows that a two-stage division can provide an NEV plaintiff with a credible threat to proceed with litigation, and enable her to extract a settlement from the defendant. A division into more than two stages can further expand the set of situations in which the plaintiff has a credible threat. To see this, suppose that $C p$ and $C d$ are 120 each as before but that $W$ is only 50. In this case, with a division of the litigation process into two equalcost stages, the plaintiff will not have a credible threat and will fail to obtain a positive settlement amount. In contrast, with a division into three equal-cost stages, and assuming that the parties have equal bargaining power (or at least that the bargaining power is not too skewed in favor of the defendant), the plaintiff will have a credible threat and succeed in extracting a positive settlement amount. Indeed, Bebchuk (1997) provides a proof that a finer division of the litigation process might sometimes improve -- and can never worsen -- the strategic position of the plaintiff and its ability to extract a settlement.

While divisibility can expand the set of circumstances in which an NEV plaintiff can obtain a settlement, divisibility cannot always provide an NEV plaintiff with a credible threat. There are cases of NEV suits in which, no matter how finely the litigation process is divided, the 
plaintiff will not have a credible threat. An analysis of the factors that determine when divisibility can and cannot provide a credible threat can be found in Bebchuk (1996) and, more fully, in Bebchuk (1997) Moreover, as Klement (2003) shows, defendants who hold private information may stonewall and sometimes deter plaintiffs from bringing NEV suits, notwithstanding divisibility of their litigation costs. Schwartz and Wickelgren (2009) examine the robustness of the analysis in Bebchuk (1996) to bargaining structures with outside options, and argue that divisibility cannot restore credibility when parties have an option to postpone a court decision indefinitely.

\section{(3) UPFRONT COSTS BY THE DEFENDANT.}

Another explanation for the success of NEV plaintiffs, which was put forward by Rosenberg and Shavell (1985), can apply even if the plaintiff's litigation costs are not at all divisible. Rosenberg and Shavell focused on those situations in which, after the plaintiff files a suit at no or little cost, the defendant must incur some significant costs of responding (because failure to respond would lead to default or summary judgment against the defendant) before the plaintiff has to incur any costs. Because only the defendant must incur costs during the initial stage of litigation (the first stage is a "cost-free" stage for the plaintiff), the plaintiff can credibly threaten to proceed through the first stage and thus impose the upfront costs on the defendant. In this situation, even if the defendant knows that the plaintiff will drop the case once the defendant responds and incurs its upfront costs, the defendant will be willing to pay a settlement (which might be up to the costs of responding) to avoid incurring these upfront costs. As Rosenberg and Shavell (2006) demonstrate, if defendants can ask the court to prevent early settlements by refusing to enforce them, they can deter plaintiffs from brining NEV suits.

Bebchuk (1996) generalizes the Rosenberg-Shavell point by combining cost-free stages with divisibility of the litigation process. Suppose that the plaintiff is expected to have a cost-free stage at some point during the litigation process. Then, it can be shown that, if the defendant's cumulative expenses up to the cost-free stage are expected to be sufficiently large compared with the plaintiff's cumulative expenses up to that stage, the plaintiff will have a credible threat to begin with and will be able to extract a settlement.

\section{(4) NEW INFORMATION AT INTERMEDIATE POINTS.}


During the litigation process, the parties might get some additional information which might lead them to revise their estimate of the expected value of the judgment. Thus far, we have assumed that the parties' estimate of the expected value of the judgment is expected to remain below total litigation costs throughout the litigation. Under this assumption, getting a settlement is the only way in which the plaintiff might end up with a positive return from the litigation. Cornell (1990) and Landes (1993) extend the analysis to cases in which the plaintiff might get favorable information at some intermediate point which may turn the plaintiff's suit into a positive-expected-value suit. If the plaintiff does not get such favorable information, he will drop the suit at that point and save his remaining litigation costs. The plaintiff thus has an option whether to progress with litigation or not. If she does not exercise this option then she does not incur the remaining costs.

To give a simple example, suppose that the judgment can be either 0 or 200 with equal probabilities, so the expected judgment, $W$, is 100 , and that $C p$ is 120 . Since litigation costs are higher than the expected judgment this is an NEV suit. Suppose, however, that litigation is divided into two equal-costs stages, and that the plaintiff learns the value of the judgment between the two stages. Unlike Bebchuk (1996), suppose also that the parties do not expect to bargain between the two stages (Grundfest and Huang (2006) combine the two models and allow bargaining between stages, when costs are divisible and information can be revealed throughout the litigation).

In this case, the plaintiff will pursue litigation only if she learns that the judgment is 200, leaving her with a net 140 . Since the probability that the judgment would be 200 is 0.5 , this implies that the plaintiff's expected value from litigation, before incurring her first stage litigation costs, is 70 , and since it is higher than her initial costs, 60 , her litigation threat is credible and she might extract a settlement offer.

\section{(5) REPEAT PLAYING AND REPUTATION.}

Thus far the analysis has focused on one shot litigation. But if any one of the parties is a repeat player, this party might develop a reputation which might enable it to bind itself to take a different course of action than the one that it would be expected to take in the case of one-shot litigation.

To begin, even if none of the factors that have been thus far considered is present, a 
plaintiff with an NEV suit might nonetheless succeed in extracting a settlement if the plaintiff or his lawyer is a repeat player with reputation of going to trial if a settlement is refused in cases of this sort. This reputation would provide the plaintiff with a credible threat to go to trial, and the credibility of this threat might induce the defendant to settle (see Farmer and Pecorino (1996)). On the other hand, even if some of the factors discussed above are present to an extent that would enable an NEV plaintiff to extract a settlement offer in a one-shot litigation, the plaintiff might not succeed in extracting an offer if the defendant is a repeat player with reputation of not settling cases of this sort (see Miceli (1993)).

\section{(6) CONTINGENT FEES AND RETAINER ARRANGEMENTS.}

Thus far, we have abstracted from the nature of the contract between the plaintiff and the plaintiff's lawyer. But, as Croson and Mnookin (1996), Bebchuk and Guzman (2000) and Chen (2006) point out, the plaintiff might be able to create a credible threat to go to trial by using a contingency fee or a retainer arrangement.

To see how lawyer-client arrangements might affect the plaintiff's credibility, consider a case in which $W$ is 100 . Suppose that the litigation costs to the plaintiff consist only of attorney fees, and let us further suppose that, if the plaintiff were to pay its lawyer on an hourly fee basis, $C p$ would be 125 -- made of 20 for hours spent on the preparatory stage before settlement negotiations take place and 105 for hours spent on the trial that would take place in the event of no settlement. Under an hourly fee arrangement, the plaintiff's suit is of course an NEV one.

Now consider what would happen if the plaintiff were to hire its lawyer on a contingency fee with the lawyer promised $20 \%$ of the plaintiff's recovery (whether in settlement or in judgment). In this case, when the parties reach the stage of settlement negotiations, the plaintiff will have a credible threat to go to trial if the defendant refuses to settle for at least 100 . Thus, with such a contingency fee arrangement, the parties can be expected to settle after the initial preparatory stage for an amount of 100 or more. It remains to consider why the lawyer would agree to such a contingency fee arrangement. But if the parties can indeed be expected to settle for at least 100 after the initial stage of preparations, being promised $20 \%$ of the expected settlement would be sufficient to compensate the lawyer for the actual work that the lawyer would be expected to do during the preparatory stage. 
NORMATIVE IMPLICATIONS. In closing, we wish to highlight the fact that the literature that this essay surveys has largely focused on positive analysis -- on understanding the conditions under which NEV suits will be brought and succeed. The conclusion that the literature has reached -- that NEV plaintiffs can in many cases succeed in extracting a settlement -suggests that the threat of using legal sanctions can provide plaintiffs with recovery in a larger set of circumstances than had been recognized by the preceding literature. This feature of the legal system might sometimes have beneficial consequences and sometimes undesirable ones.

With respect to NEV suits that are meritorious (and are NEV simply because the required litigation costs would be large relative to the amount at stake), an NEV plaintiff's ability to extract a settlement offer might well be socially beneficial. In contrast, with respect to NEV suits that are frivolous, an NEV plaintiff's ability to extract a settlement offer might well have undesirable consequences.

The literature surveyed here shows that the partition of all lawsuits to those that can extract a positive settlement and those that cannot does not necessarily overlap with the partition between NEV suits and PEV suits. As Shavell (1997) aptly demonstrates, neither partition overlaps with that between socially desirable and socially undesirable lawsuits.

Now that we have obtained some substantial understanding concerning when NEV suits can succeed, the challenge for future work in this area is to design rules and policies that would produce as close a correlation as possible between the success and merits of NEV suits. 


\section{BIBLIOGRAPHY}

Bebchuk, L.A. 1984. Litigation and settlement under imperfect information. Rand Journal of Economics 15, 404-415.

Bebchuk, L.A. 1988. Suing solely to extract a settlement offer. Journal of Legal Studies 17, 437449.

Bebchuk, L.A. 1996. A new theory concerning the credibility and success of threats to sue. Journal of Legal Studies 25, 1-25.

Bebchuk, L.A. 1997. On divisibility and credibility: the effects of the distribution of litigation costs over time on the credibility of threats to sue. Working paper, Harvard Law School, Cambridge, MA.

Bebchuk, L.A. 2000. Suits with Negative Expected Value, 3 The New Palgrave Dictionary of Economics and the Law 551-554 (1998) (University of Chicago Press, 2000)

Bebchuk, L.A. and Guzman, A. 2000. The impact of fee arrangements on the credibility of threats to sue. Unpublished manuscript, Harvard Law School, Cambridge, MA.

Chen, Zhiqi 2006. Nuisance Suits and Contingent Attorney Fees. 2 Review Of Law And Economics 2, 363-370.

Cornell, B. 1990. The incentive to sue: an option pricing approach. Journal of Legal Studies 19, 173-187.

Farmer, A. and Pecorino, P. 1998. A reputation for being a nuisance: frivolous lawsuits and fee shifting in a repeated play game. International review of law and economics 18, 147-157.

Gould, J.P 1973. The economics of legal conflicts. Journal of Legal Studies 2, 279-300.

Grundfest, J.A. and Huang, P.H.. (2006). The unexpected value of litigation: A real options perspective. Stanford Law Review 58, 1267-1336.

Katz, A. 1990. The effect of frivolous lawsuits on the settlement of litigation. International Review of Law and Economics 10, 3-27.

Klement, A. 2003. Threats to sue and cost divisibility under asymmetric information. International Review of Law and Economics 23, 261-272.

Landes, W.M. 1971. An economic analysis of the courts. Journal of Law and Economics 14, 61107. 
Landes, W.M. 1993. Sequential versus unitary trials: an economic analysis. Journal of Legal Studies 22, 99-134.

Miceli, T.J. 1993. Optimal deterrence of nuisance suits by repeat defendants. International Review of Law and Economics 13, 135-144.

Croson, D. and R. Mnookin. 1996. Scaling the Stonewall: Retaining Lawyers to Bolster Credibility. 1 Harv. Neg'n L. Rev., 65-83.

P'ng, I. 1983. Strategic behavior in suit, settlement, and trial. Bell Journal of Economics 14, 539550.

Posner, R.A. 1973. An economic approach to legal procedure and judicial administration. Journal of Legal Studies 2, 399-458.

Reinganum J. F and Wilde L. F. 1986. Settlement, litigation, and the allocation of litigation costs. RAND J. Econ. 17, 557-566

Rosenberg, D. and Shavell, S. 1985. A model in which suits are brought for their nuisance value. International Review of Law and Economics 5, 3-13.

Rosenberg, D. and Shavell, S. 1985. A solution to the problem of nuisance suits: The option to have the court bar settlement. International Review of Law and Economics 26, 42-51.

Schwartz, W.F. 2003. Can suits with Negative expected value really be profitable, Legal Theory 9, 83-97

Schwartz, W.F. and Wickelgren, A.L. 2009. Advantage defendant: why sinking litigation costs makes negative-expected-value defenses but not negative-expected-value suits credible. Journal of Legal Studies 38, 235-253.

Shavell, S. 1997. The fundamental divergence between the private and the social motive to use the legal system, Journal of Legal Studies, 26:575-613. 